\title{
CHEMICAL COMPOSITION OF THE UROLOGY COLLECTION
}

\author{
(C) N.T. Farmanova ${ }^{1 *}$, L.T. Pulatova ${ }^{2}$, D.I. Mambetova ${ }^{3}$, A.J. Nurullaev ${ }^{4}$, D.K. Khudoykulova ${ }^{1}$ \\ ${ }^{1}$ Tashkent Pharmaceutical Institute, st. Aybek, 45, Tashkent, 100015 (Uzbekistan), \\ e-mail: farmanovan70@mail.ru \\ ${ }^{2}$ Higher Military Customs Institute of the Republic of Uzbekistan, \\ st. Kozirobod, 118, Tashkent, 100071 (Uzbekistan) \\ ${ }^{3}$ Scientifically research University of Technologies, Moscow Institute of steel and \\ alloy, st. A. Timur, 56, Almalik, 110100 (Uzbekistan) \\ ${ }^{4}$ Tashkent Medical Academy, st. Farobiy, 2, Tashkent, 210109 (Uzbekistan)
}

In order to identify the main biologically active complex, there were carried out a chemical analysis of the urological collection. As a result of the study, there were established the presence of water-soluble polysaccharides in the urological collection $3.2 \pm 0.3 \%$, amino acids $-406.3 \pm 0.01 \mathrm{nmol}$, ascorbic acid $45.0 \pm 0.5 \mathrm{mg} \%$, carotenoids $0.50 \pm 0.04 \mathrm{mg} \%$, organic acids $1.87 \pm 0.2 \%$, essential oil $-0.79 \pm 0.1 \%$, flavonoids $-0.43 \pm 0.04 \%$, coumarins $-0.18 \pm 0.2 \%$, phenolcarboxylic acids $-0.41 \pm 0.2 \%$, tannins $-5.3 \pm 0.4 \%$, saponins (glycyrrhizic acid) $-1.15 \pm 0.2 \%$, as well as macro- and micronutrients $-19596.65 \pm 0.002 \mathrm{mg} / \mathrm{kg}$. The elemental composition of the collection is represented by 17 vital elements ( $\mathrm{K}, \mathrm{Ca}, \mathrm{Mg}, \mathrm{Na}, \mathrm{P}$ are the dominant components). During studies have also shown the presence of 14 amino acids, 7 of which are essential ( $44.6 \%$ of the total amino acids). It can be clearly stated that the indicator components of the collection are polyphenolic compounds (flavonoids, tannins, etc.) and saponins (glycyrrhizic acid) predominantly passing into aqueous extracts (the proposed dosage form) of the collection, the complex of which determines the specific activity of the studied urological collection. The obtained data were used to develop the authenticity and criteria of the quality of the studied collection.

Keywords: urological collection, chemical composition, glycyrrhizic acid, flavonoids, essential oils, polysaccharides.

\section{Introduction}

As you know, remedy plant collections are mixtures of several types of crushed, rarely whole remedy plant materials, sometimes with the addition of salts of essential oils, which have several advantages (the complex effect of biologically active substances in the components of the collection, the presence of active substances in the raw material in its original form, the simplicity of their preparation and the availability of raw materials). The therapeutic effectiveness of the collection is a manifestation of the general laws of synergism of active and associated substances, the summation and potentiation of their pharmacological effects [1-3]. Despite the increase in the arsenal of plant collection is permitted for medical use in Uzbekistan, practical medicine needs to develop and introduce new effective import-substituting compositions based on raw materials of local medicinal plants, in particular, diuretic ones, as the share of domestic herbal diuretics in the list of drugs is low [4]. In this regard, based on the study biologically

Farmanova Nodira Takhirovna - Associate Professor of the Department of Pharmacognosy, e-mail: farmanovan70@mail.ru

Pulatova Lola Tairkhanovna - Professor of the Department of Customs Expertise and Classification of Goods, e-mail: lorena_97@mail.ru

Mambetova Dildor Irgashevna - Associate Professor, e-mail: mambetova_d@mail.ru

Nurullaev Arzikul Dzhurakulovich - Deputy Dean of the Faculty of Medicine, e-mail: aurum_dilobar.pp@mail.ru Khudoykulova Dlafruz Kabiljanovna-Senior Lecturer of the Department of Languages,

e-mail: khudoykylova_1982@mail.ru active plant compounds, the experience of their use in official and traditional medicine, as well as the etiology and pathology of the urinary system, the composition of a new urological collection has been developed, including domestic medicinal plant material: flowers of yarrow tea leaves (P. Achillea filipendulina L.) - $30 \mathrm{~g}$, peduncle zizifora grass (P. Ziziphora pedicellata) -30 $\mathrm{g}$ and licorice roots (P. Glycyrrhiza glabra L.) - $30 \mathrm{~g}$. Preclinical pharmacological studies were carried out at the Department of Pharmacology of the Tashkent Pharmaceutical Institute showed a high diuretic activity of

\footnotetext{
${ }^{*}$ Corresponding author.
} 
this sample (increases diuresis by 68.6\%) [5]. When standardizing the raw materials of medicinal plants and compositions based on them, a mandatory element is a chemical assessment of the content of biologically active substances that determine the medicinal value. In this regard, the objective of our research was to study the characteristics of the qualitative and quantitative composition of the active substances of the urological collection in order to identify their main biologically active complex.

\section{Experimental part}

The object of the study was the samples of urological collection, which was prepared in accordance with the requirements of the article "Collections" SPh XI [6]. The degree of grinding of raw materials is $7 \mathrm{~mm}$. Herbal raw materials for preparation were harvested at different phases of vegetation from botanically reliable plants: bare licorice roots were harvested at the end of the growing season, peduncle zisiphor grass and flowers of the fernleaf yarrow during mass flowering of plants within their natural range - on the slopes of the Chimgan mountains of the Chatkal mountain range Thian-Shan (2011-2012). The climatic conditions of the Chimgan Mountains are determined by the mountainous part of Ugam-Chatkal National Park. The climate is continental, there are seasonal and daily temperature fluctuations. Samples of medicinal plants were determined by F.M. Dustmuratova. Herbarium samples are stored in the collection of the Botanical Research Institute of the Academy of Sciences of the Republic of Uzbekistan

The prepared collection was stored for analysis in the laboratory in dark glass jars with ground stopper. The analysis was performed in an average sample in five replicates.

The urological collection is a mixture of whole flower baskets with the remains of peduncles and individual flowers of the yarrow with shredded leaves, stems and flowers of the Ziziphorae pedicellatae and pieces of roots and underground shoots of licorice. Yarrow basal leaves are oblong-ovate with a multi-row, tiled greenish-yellow wrap and yellow reed and tubular flowers. The leaves of the Ziziphorae pedicellatae of the centipede are gray-green, bare or scattered fluffy, the pieces of the stems are tetrahedral, finely fluffy, often purple-colored, the flowers are light purple. The smell is peculiar, fragrant. The taste is spicy sweet, slightly annoying.

The study of the chemical composition for the content of the main groups of biologically active substances was carried out using well-known qualitative reactions, chromatography methods on paper and in thin layers of the sorbent [7-17].

For chromatographic analysis we used FN-3 brand paper (German, Mittelschnell laufend), as well as a Merck chromatographic plate with silica gel 60 F 254 on an $7.5 \times 15$ cm aluminum substrate (or "Silufol" UV-254, size 7.5 $\times 15 \mathrm{~cm}$ ) . A chromatographic study of the biologically active substances of the collection was carried out on aqueous, hexane and alcohol extracts $(70 \%)(1: 10)$. Extract was concentrated under vacuum, the residue was dissolved in $95 \%$ ethanol and chromatographed in an ascending manner. The application of the studied solutions on chromatographic plates was carried out using micro syringes. Chromatography was performed in an appropriate solvent system at a temperature of $18-22{ }^{\circ} \mathrm{C}$ in hermetically sealed glass chambers. All $\mathrm{R}_{\mathrm{f}}$ values of the detected compounds are the average of five measurements. Chromatographic solvents and reagents used ChP or PfA brands. Phenolic compounds were detected in UV light before and after the appearance of chromatograms with appropriate reagents (alcohol solutions of aluminum chloride and sodium hydroxide, ammonia solution, diazoragent).

When chromatographing the aqueous extraction on paper in a solvent system of butanol - acetic acid - water ( $4: 1: 5$ ), the presence of the following substances was confirmed: organic acids (malic $\left(\mathrm{R}_{\mathrm{f}} 0.57\right)$, citric $\left(\mathrm{R}_{\mathrm{f}} 0.48\right)$, oxalic $\left(R_{f} 0.62\right)$, developer $-0.04 \%$ solution of bromphenolblow); free sugars (maltose $\left(R_{f} 0.30\right)$, glucose $\left(R_{f} 0.49\right)$, sucrose $\left(R_{f} 0.38\right)$, fructose $\left(R_{f} 0.63\right)$, xylose $\left(R_{f} 0.77\right)$, developer - Felling reagent); ascorbic acid $\left(R_{f} 0.42\right.$, developer - Tillmans reagent).

Polysaccharides were isolated by ethanol precipitation [17]. The monosaccharide composition was determined after hydrolysis by the following procedure: $2.5 \mathrm{ml}$ of $2 \mathrm{M}$ sulfuric acid was added to $0.05 \mathrm{~g}$ of polysaccharide in a boiling water bath for 8 hours. Next for barium carbonate was added to neutralize and then treated with KU-2 cation exchanger $\left(\mathrm{H}^{+}\right.$-form), concentrated and chromatographed simultaneously with reliable samples on paper in systems for neutral sugars - butanol- pyridine - water $(6: 4: 3)$ and for acid sugars - ethyl acetate - acetic acid formic acid - water $(18: 3: 1: 4)$. An acid solution of aniline phthalate and heat treatment were used to detect sugars. As a result of chromatographic analysis, it was found that the polysaccharide collection complex includes neutral monosaccharides: L-arabinose, D-glucose and D-xylose.

Collection glycyrrhizic acid was determined using a "Merck" chromatographic plate with 60 F254 silica gel on an $7.5 \times 15 \mathrm{~cm}$ aluminum substrate (or "Silufol" grade UV-254 $7.5 \times 15 \mathrm{~cm}$ in size). $0.01 \mathrm{ml}$ of the obtained 
analytical samples were applied with a micropipette and near $0.01 \mathrm{ml}(10 \mathrm{mg})$ of a $0.1 \%$ solution of working standard sample of glycyrrhizic acid. The plate with the deposited samples was dried in air for 30 min, then placed in a chamber, which was preliminarily saturated with a mixture of solvents: chloroform - methanol - water in a volume ratio of $26: 14: 3$ and chromatographed in an ascending manner. When the front of the solvents passed $12-13 \mathrm{~cm}$, the plate was removed from the chamber, dried in air for 20 minutes, and viewed in UV light at a wavelength of 254 $\mathrm{nm}$. On the chromatogram at the level of the working standard sample spot of glycyrrhizic acid, a dirty violet spot was found. When a chromatogram was developed with a solution of vanillin in concentrated sulfuric acid, the spot upon heating gave an off-violet color, turning into blue over time.

Further, for preliminary qualitative detection of amino acids, were carried a reaction out with an alcohol solution of ninhydrin [18]. The appearance of violet staining revealed the presence of amino acids in the harvest extracts. Chromatographic study was carried out by the method of ascending thin-layer chromatography in a solvent system of butanol - acetic acid - water $(4: 1: 2)$. When processing the chromatographic plate with a $0.2 \%$ solution of ninhydrin in acetone (heated in an oven at a temperature of $105{ }^{\circ} \mathrm{C}$ for $2-3$ minutes), the amino acids in the visible light appeared as pink-purple spots.

Since it was not possible to identify thin layer chromatography found in the aqueous extraction of amino acids, an amino acid analyzer was used for this purpose. About $1 \mathrm{~g}$ (accurately weighed) of the collection was placed in a round bottom flask with a thin section, $20 \mathrm{ml}$ of purified water was added and heated in a water bath under reflux for $1 \mathrm{~h}$. Then it was cooled to room temperature. The obtained extract was filtered through a cotton swab inserted in a glass funnel with a diameter of $3 \mathrm{~cm}$. The first $10 \mathrm{ml}$ of the filtrate was discarded. An aliquot of $50 \mathrm{ml}$ was taken from a subsequent batch of filtrate and evaporated to dryness. Then, to carry out hydrolysis, the dry residue was placed in a glass ampoule, $5 \mathrm{ml}$ of $6 \mathrm{~N} \mathrm{HCl}$ was added, the ampoule was sealed and kept in a thermostat at a temperature of $110^{\circ} \mathrm{C}$ for 24 hours.

Amino acid composition of water-soluble fractions after hydrolysis was determined on a T-339 amino acid analyzer ("Mikrotehna", Prague) with program control. The analytical column "Ostion LG ANB" (3.7 × $45 \mathrm{~cm})$. For separation, stepwise elution with buffer solutions was used: $0.3 \mathrm{M}\left(\mathrm{Na}^{+}\right)$citrate-hydrochloric acid $\mathrm{pH} 3.5$ at $46{ }^{\circ} \mathrm{C}$ (buffer solution A); $0.4 \mathrm{M}\left(\mathrm{Na}^{+}\right)$citrate hydrochloric acid $\mathrm{pH} 4.25$ at $46{ }^{\circ} \mathrm{C}$ (buffer solution $\mathrm{B}$ ); $0.45 \mathrm{M}\left(\mathrm{Na}^{+}\right)$citrate hydrochloric acid $\mathrm{pH} 9.45$ at $62{ }^{\circ} \mathrm{C}$ (buffer solution B). Pumping time sequentially with buffer solution $\mathrm{A}$ is 17 minutes, $\mathrm{B}$ is 25 minutes, and $\mathrm{C}$ is 48 minutes. The reagent is ninhydrin, pumping rate $-8 \mathrm{ml} / \mathrm{h}$.

To calculate and interpret the peaks in the obtained chromatograms, we used the integrator, which is equipped with an amino acid analyzer.

It was found that the amino acid composition of the new urological collection is represented by 14 amino acids, including 7 essential ones (valine, methionine, isoleucine, leucine, tyrosine, phenylalanine, lysine).

Substances of a carotenoid nature were determined in hexane extraction by thin layer chromatography on plates in a solvent system of hexane - diethyl ether $(17: 3)$. As a result, 3 substances were found in the form of a blue spot on a yellow-green background after treatment with a $10 \%$ alcohol solution of phosphoromolybdenum acid and heating at a temperature of $70-80^{\circ} \mathrm{C}$, which were identified as $\beta$-carotene $\left(\mathrm{R}_{\mathrm{f}} 0.48\right)$ neo $\beta$-carotene $\left(\mathrm{R}_{\mathrm{f}} 0.62\right)$ and $\alpha$-carotene $\left(\mathrm{R}_{\mathrm{f}} 0.83\right)$.

Coumarins were determined by extraction with 95\% ethanol in the cold for 24 hours, followed by centrifugation of the extract at a speed of 4.5 thousand rpm for 7 minutes. Then the extraction was filtered and chromatographed on Sorbfil plates in a solvent system of n-butanol-glacial acetic acid - water $(4: 1: 2)$. Coumarins were detected in the chromatogram by fluorescence in UV light $(365 \mathrm{~nm})$. As a result, 6 spots with $\mathrm{R}_{\mathrm{f}}$ were detected $0.13 ; 0.17 ; 0.21 ; 0.28 ; 0.35$ and 0.50 , having a bright blue, slightly green-blue and blue fluorescence and giving a positive reaction with Pauli's reagent. This fact made it possible to attribute the discovered substances to coumarins. Further, when comparing the detected substances with authentic samples of "witnesses", three of them are identified as umbelliferone $\left(R_{f} 0.13\right)$, scopoletin $\left(R_{f} 0.21\right)$ and esculletin $\left(R_{f} 0.28\right)$.

Phenolcarboxylic acids were isolated using an alcoholic extract collection. Chromatography was performed on a polyamide sorbitol column, elution was carried out with water. The obtained fractions were combined, phenolcarboxylic acids were extracted from aqueous eluates (acidified to $\mathrm{pH} 3$ ) with ethyl acetate. Then, ethyl acetate extracts were evaporated and chromatographed in a system of $2 \%$ acetic acid. When chromatograms were developed with diazotized sulfanilic acid, the presence of at least 5 phenol carboxylic acids was determined, of which 3 were identified by comparison with reliable samples of substances (Tab. 1).

The presence of flavonoids in alcoholic extracts of the collection was also established by paper chromatography in a solvent system of butanol - acetic acid - water $(4: 1: 5)$. Under similar conditions, reliable witness samples were separated using standards of rutin, quercetin, cinaroside, luteolin and hyperoside. 
Table 1. Data of chromatographic analysis of the isolated phenolcarboxylic acids of the urological collection

\begin{tabular}{c|c|c|c}
\hline $\begin{array}{c}\mathrm{R}_{\mathrm{f}} \text { value in the system } \\
2 \% \mathrm{CH}_{3} \mathrm{COOH}\end{array}$ & UV fluorescence & $\begin{array}{c}\text { Color stains after treatment } \\
\text { DSC* }\end{array}$ & $\begin{array}{c}\text { Identified phenol carboxylic } \\
\text { acids }\end{array}$ \\
\hline 0.16 & orange red & red & protocatech \\
0.26 & blue & orange red & red \\
0.28 & orange red & chlorogenic \\
\hline
\end{tabular}

*-diazotized sulfanilic acid

After the chromatogram was developed with an alcohol solution of aluminum chloride, as well as ammonia vapors, the color of the spots in the UV light changed to bright yellow, green-yellow, or yellow. When comparing the detected flavonoids with authentic "witness" samples, 5 of them were identified as rutin $\left(\mathrm{R}_{\mathrm{f}} 0.45\right)$, cinaroside $\left(\mathrm{R}_{\mathrm{f}}\right.$ $0.48)$, hyperoside $\left(\mathrm{R}_{\mathrm{f}} 0.55\right)$, quercetin $\left(\mathrm{R}_{\mathrm{f}} 0.78\right)$ and luteolin $\left(\mathrm{R}_{\mathrm{f}} 0.85\right)$.

Then, after conducting qualitative reactions and chromatographic studies of biologically active substances, were carried out a quantitative analysis of the detected compounds. The quantitative content of the detected compounds was determined by the following methods: tannins using the method of permanganatometry [8], flavonoids, glycyrrhizic acid, phenolcarboxylic acids and carotenoids using the spectrophotometric method [11-15], coumarins (after extraction with chloroform) [16] and polysaccharides (after deposition ethanol) - gravimetric method [17], ascorbic acid and organic acids - titrimetrically [7], the total content of free amino acids was determined on an amino acid analyzer [18], the content mineral elements were determined in parallel with the identification by ICP-mass spectral analysis. The quantitative content of micro- and macrocells of the test collection was studied by ICP-mass spectral analysis on an ICP-MS (induction-coupled plasma mass spectrometer) AT 7500 in the Semiquant mode according to the Test.M method [19, 20].

Instrument parameters: ICP-MS (induction-coupled plasma mass spectrometer) AT 7500 plasma power 1200 $\mathrm{W}$, integration time $0.1 \mathrm{sec}$. Calibration of the device and quantitative calculation were carried out on the basis of the multi-element calibration standard of the company "Agilent Technologist", 22 elements.

As a result of the analysis, the macro- and microelement composition of the urological collection was established. The data obtained are presented in table 2 .

As can be seen from table 2, in the urological collection revealed 17 elements, of which $\mathrm{K}, \mathrm{Ca}, \mathrm{Mg}, \mathrm{Na}, \mathrm{P}$ are quantitatively predominant and contribute to enhancing the biological value of this drug. In particular, potassium supports osmotic pressure in the blood, has a diuretic effect, sodium also participates in the regulation of osmotic pressure, metabolism, in support of alkaline-acid balance, etc.

The amount of identified amino acid was determined in nanomoles. Then, the quantitative content of the detected free amino acids was calculated as a percentage of the total amount of amino acids (Tab. 3).

In the studied collection, 14 free amino acids were found, among which glutamic acid (13.1\%), glycine (12.4\%), aspartic acid and histidine (11.5\%) prevailed in quantitative terms.

Table 2. The quantitative content of micro and macro elements of the urological collection

\begin{tabular}{c|c|c}
\hline № & Elements & The content of the collection, $\mathrm{mg} / \mathrm{kg}$ \\
\hline 1 & Aluminum, Al & 340 \\
2 & Arsenic, As & 38 \\
3 & Barium, Ba & 32 \\
4 & Calcium, Ca & 5280 \\
5 & Chrome, Cr & 120 \\
6 & Cuprum, Cu & 15 \\
7 & Iron, Fe & 1440 \\
8 & Potassium, K & 960 \\
9 & Magnesium, Mg & 1520 \\
10 & Sodium, Na & 960 \\
11 & Strontium, Sr & 40 \\
12 & Zinc, Zn & 42 \\
13 & Lead, Pb & 5.8 \\
14 & Iodine, I & 8.8 \\
15 & Antimony, Sb & 1.01 \\
16 & Mercury, Hg & 0.05 \\
17 & Phosphorus, P & 154 \\
\hline Total & & 19596,65 \\
\hline
\end{tabular}


Table 3. Amino acid composition of the urological collection

\begin{tabular}{|c|c|c|}
\hline \multirow{2}{*}{ Amino acids } & \multicolumn{2}{|c|}{ Amounts of free and bound amino acids after hydrolysis } \\
\hline & nmol & $\%$ of total amino acids \\
\hline \multicolumn{3}{|c|}{ Monoaminomonocarboxylic acids } \\
\hline Alanine ( $\alpha$-aminopropionic acid) & 32.0 & 7.9 \\
\hline Glycine (aminoacetic acid) & 50.2 & 12.4 \\
\hline Methionine* $(\alpha$-amino- $\gamma$-methylthiol-n-butyric acid) & 10.6 & 2.6 \\
\hline Valine $^{*}(\alpha$-aminoisovalerianic acid $)$ & 16.4 & 4.0 \\
\hline Serine ( $\alpha$-amino- $\beta$-hydroxypropionic acid) & 19.0 & 4.7 \\
\hline Isoleucine* ( $\alpha$-amino- $\beta$-ethyl- $\beta$-methyl-propionic acid & 14.9 & 3.7 \\
\hline Leucine* ( $\alpha$-aminoisocaproic acid) & 23.3 & 5.7 \\
\hline Phenylalanine* ( $\alpha$-amino- $\beta$-phenylpropionic acid) & 30.0 & 7.4 \\
\hline Tyrosine* ( $\alpha$-amino- $\beta$-hydroxyphenylpropionic acid $)$ & 23.4 & 5.8 \\
\hline \multicolumn{3}{|c|}{ Monoaminodicarboxylic acids } \\
\hline Aspartic Acid (Amino Acid) & 46.9 & 11.5 \\
\hline Glutamic acid ( $\alpha$-aminoglutaric) & 53.4 & 13.1 \\
\hline \multicolumn{3}{|c|}{ Diaminodicarboxylic acids } \\
\hline Lysine* $(\alpha, \varepsilon$-diaminocaproic acid $)$ & 15.7 & 3.9 \\
\hline \multicolumn{3}{|c|}{ Heterocyclic amino acids } \\
\hline Histidine ( $\alpha$-amino- $\beta$-imidazolylpropionic acid) & 46.8 & 11.5 \\
\hline Proline (pyrrolidine- $\alpha$-carboxylic acid) & 23.7 & 5.8 \\
\hline Essential Amino Acids & & 44.6 \\
\hline
\end{tabular}

* - Essential amino acids.

\section{Discussion of the results}

As a result of a chemical study in the urological collection, the presence of water-soluble polysaccharides $3.2 \pm 0.3 \%$, amino acids $-406.3 \pm 0.01 \mathrm{nmol}$, ascorbic acid $-45.0 \pm 0.5 \mathrm{mg} \%$, carotenoids $-0.50 \pm 0,04 \mathrm{mg} \%$, organic acids $-1.87 \pm 0.2 \%$, essential oils $-0.79 \pm 0.1 \%$, flavonoids $-0.43 \pm 0.04 \%$, coumarins $-0.18 \pm 0.2 \%$, phenolcarboxylic acids $-0.41 \pm 0.2 \%$, tannins $-5.3 \pm 0.4 \%$, saponins (glycyrrhizic acid) $-1.15 \pm 0.2 \%$, and macro and macro elements $19596.65 \pm 0.002 \mathrm{mg} / \mathrm{kg}$ (Tab. 4).

Obviously, the indicator components of the collection are polyphenolic substances (flavonoids, tannins, etc.) and saponins (glycyrrhizic acid) that predominantly pass into aqueous extracts (the proposed dosage form) of the collection, the complex of which determines the specific activity of the studied urological collection. In addition, the elemental composition represented by 17 vital elements, of which $\mathrm{K}, \mathrm{Ca}, \mathrm{Mg}, \mathrm{Na}, \mathrm{P}$ are the dominant components contribute to enhancing the diuretic effect of the studied collection. In particular, potassium maintains osmotic pressure in the blood, has a diuretic effect, sodium also participates in the regulation of osmotic pressure, metabolism, in support of alkaline-acid balance, etc. As well as 7 essential amino acids found in the collection, which make up $44.6 \%$ of total amino acids show the high biological value of the studied dosage form.

Table 4. The results of determining the qualitative composition and quantitative content of biologically active compounds of the urological collection $(n=5)$

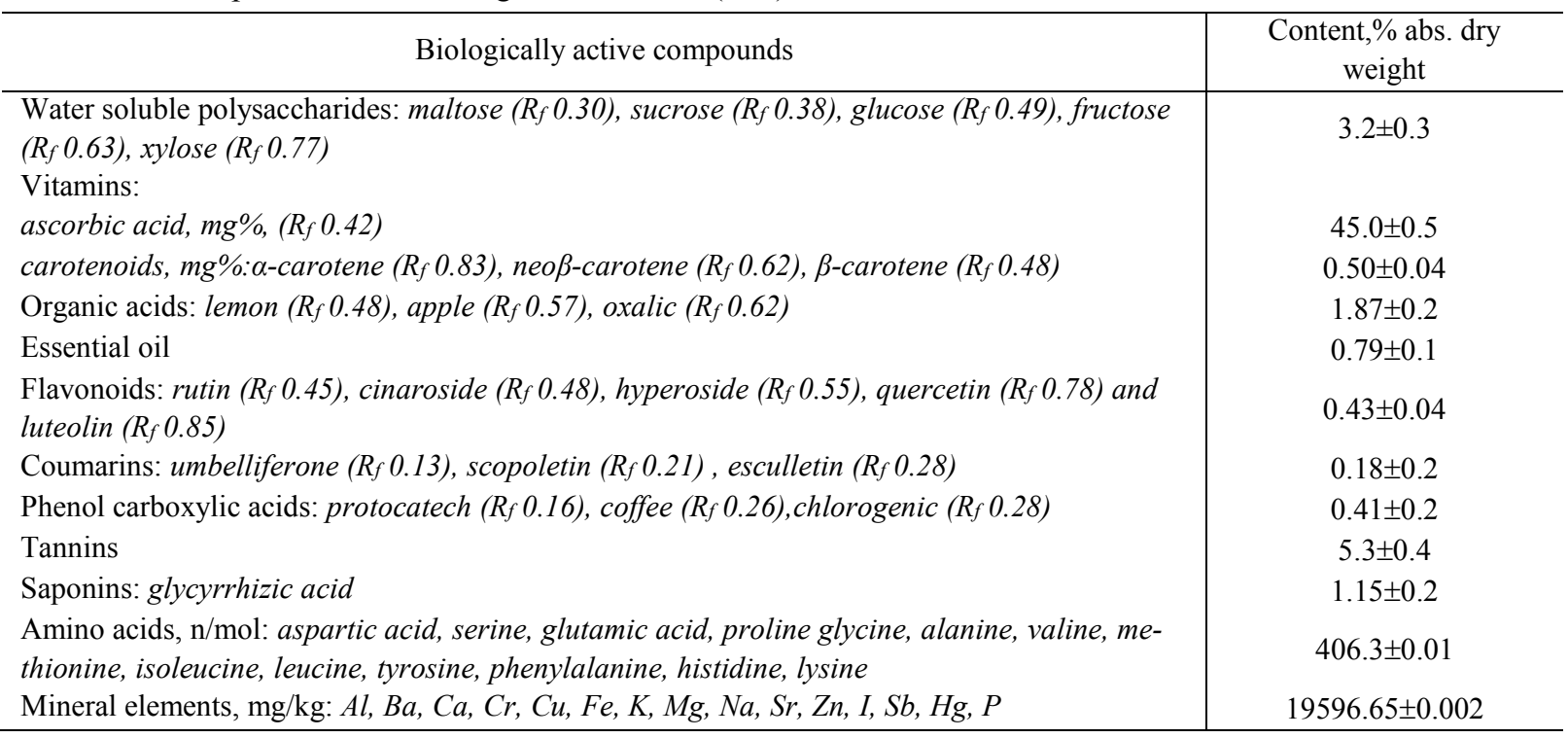




\section{Conclusion}

According to the detailed study, the chemical profile of the urological collection was established, the indicator compounds of which are polyphenolic substances (flavonoids, tannins, etc.) and saponins (glycyrrhizic acid). In addition, the qualitative composition and quantitative content of amino acids, macro- and microelements, ascorbic acid, polysaccharides, carotenoids, coumarins and other biologically active compounds has been established. The data obtained were used to develop the authenticity and criteria of the quality of the studied collection.

\section{References}

1. Samylina I.A., Balandina I.A. Farmatsiya, 2003, vol. 52 (2), pp. 39-41. (in Russ.).

2. Korsun V.F., Korsun E.V. Fitoterapiya: traditsii rossiyskogo travnichestva (Noveyshiy meditsinskiy spravochnik). [Phytotherapy: traditions of Russian herbalism (The latest medical reference book)]. Moscow, 2010, 879 p. (in Russ.).

3. Mosolova Yu.E., Khakhulina N.N. Bulletin of Medical Internet Conferences, 2013, vol. 3, no. 2, p. 372. (in Russ.).

4. Gosudarstvenniy reestr lekarstvennix sredstv i meditsinskix izdeliy. Ofitsialnoe izdanie (po sostoyaniyu na 19 fevralya $2020 \mathrm{~g}$ ). [The state register of medicines and medical devices. Official publication (as of February 19, 2020)]. (in Russ.).

5. Farmanova N.T., Urmanova, F.F., Aliev Kh.Yu. Farmatsevticheskiy zhurnal, 2009, no. 2, pp. 68-70. (in Russ.).

6. Gosudarstvennaya farmakopeya. XI izd. [The State Pharmacopoeia. XI ed.]. Moscow, 1987, vol. 1, 337 p. (in Russ.).

7. Gosudarstvennaya farmakopeya. XI izd. [The State Pharmacopoeia. XI ed.]. Moscow, 1990, vol. 2, 338 p. (in Russ.).

8. Gosudarstvennaya Farmakopeya Rossiyskoy Federatsii. XIV izd. [The State Pharmacopoeia of the Russian Federation. XIV edition]. Moscow, 2018, vol. 3, pp. 2365-2367. (in Russ.).

9. Grinkevich N.I., Safronich L.A. Khimicheskiy analiz lekarstvennykh rasteniy. [Chemical analysis of medicinal plants]. Moscow, 1983, 176 p. (in Russ.).

10. Bandyukova V.A., Shinkarenko A.A. Khimiya prirodnykh soyedineniy, 1983, no. 1, pp. 20-24. (in Russ.).

11. Beketov E.V., Abramov A.A., Nesterova O.V. Vestnik Moskovskogo universiteta. Khimiya, 2005, vol. 46, no. 4, pp. 259-262. (in Russ.).

12. Kurkin V.A., Egorov M.V. Fundamental'nyye issledovaniya, 2014, no. 6(6), pp. 1232-1236. (in Russ.).

13. Malyutina A.Yu., Shestopalova N.N., Novikov O.O., Pisarev D.I., Kazakova V.S., Tsvetkova Z.E. Nauchnyy rezul'tat. Meditsina i farmatsiya, 2016, vol. 2, no. 4, pp. 66-72. DOI: 10.18413/2313-8955-2016-2-4-66-72 (in Russ.).

14. Afanasyeva P.V., Kurkin V.A., Kurkina A.V. Izvestiya Samarskogo nauchnogo tsentra Rossiyskoy akademii nauk, 2015, vol. 1, no. 5, pp. 930-934. (in Russ.).

15. Sampiev A.M., Khochava M.R. Kalendula lekarstvennaya. [Calendula officinalis]. Krasnodar, 2010, 144 p. (in Russ.).

16. Nikonov G.K., Perelson M.E. Trudy VILR. 1969, pp. 88-125. (in Russ.).

17. Ibragimova N.A., Urmanova F.F. Materiali nauchno-prakticheskoy konferensii «Integratsiya obrazovaniya, nauki $i$ proizvodstva v farmatsii», posvyamennoy 70-letiyu Tashkentskogo farmatsevticheskogo instituta. [Materials of the scientific-practical conference "Integration of education, science and production in pharmacy", dedicated to the 70th anniversary of the Tashkent Pharmaceutical Institute]. Tashkent, 2007, pp. 137-138. (in Russ.).

18. Karpyuk U.V., Kislichenko V.S., Velma V.S., Bukharina O.V. Ukrayins'kyy zhurnal klinichnoyi ta laboratornoyi medytsyny, 2009, vol. 4, no. 2, pp. 41-44. (in Ukr.).

19. Slivkin A.I., Trineeva O.V. Vestnik Voronezhskogo gosudarstvennogo universiteta. Seriya: Khimiya. Biologiya. Farmatsiya, 2016, no. 1, pp. 152-155. (in Russ.).

20. MUK 4.1.1483-03. Opredeleniye soderzhaniya khimicheskikh elementov $\mathrm{v}$ diagnostiruyemykh biosubstratakh, preparatakh i biologicheski aktivnykh dobavkakh metodom mass-spektrometrii s induktivno svyazannoy argonovoy plazmoy. [MUK 4.1.1483-03. Determination of the content of chemical elements in diagnosed biosubstrates, preparations and biologically active additives by inductively coupled argon plasma mass spectrometry]. (in Russ.).

Received March 19, 2020

Revised November 9, 2020

Accepted December 8, 2020.

For citing: Farmanova N.T., Pulatova L.T., Mambetova D.I., Nurullaev A.J., Khudoykulova D.K. Khimiya Rastitel'nogo Syr'ya, 2021, no. 1, pp. 227-232. (in Russ.). DOI: 10.14258/jcprm.2021017542. 